\title{
Review and Enlightenment of Financial Restatement
}

\author{
Fang Gao \\ School of Business \\ Jianghan University \\ Wuhan, China \\ gaofangwh@163.com
}

\author{
Xin Zhao \\ School of Business \\ Jianghan University \\ Wuhan, China \\ 342321534@qq.com
}

\begin{abstract}
With the increasing development of capital markets, the quality of information of listed companies face higher requirements, the increasingly frequent and prevalent financial restatement has aroused widespread concern in the academic community. This paper reviews and summarizes the research of financial restatement from the aspects of motivation, company characteristics and economic consequences. It gives a brief evaluation of the domestic and foreign literatures, in order to provide useful reference for the further improvement of China's financial restatement system.
\end{abstract}

Keywords-financial restatement; motivation; company characteristics; economic consequences

\section{INTRODUCTION}

Financial statement refers to the behavior that the companies find and correct the previous financial reporting errors and restate the previously published financial statement. High quality financial information is not only the basis of effective capital market, but also is one of the essential elements for the stable development of capital market. Financial restatement indicates that the company's accounting information may exhibits the problem. Since 1990s, the frequently financial restatement of listed company has become an important issue affecting the allocation of capital market resources and the protection of the interests of investors. In this regard, foreign scholars have conducted a lot of research, and made many achievements. In China, with the rapid development of the market, the phenomenon of financial restatement is also increasing, but domestic research on this issue is less. Based on this, this paper reviews the domestic and foreign research, and prospects for the future research.

\section{Motivation of FinAnCial Restatement}

\section{A. Executive Compensation}

Some foreign scholars put the perspective on the income of stock and options based on the compensation contract. The primary purpose of executive compensation contract is to alleviate agency conflicts, but the difference of the performance indicators affects the effectiveness of the compensation contract. Executives will manipulate earnings and then correct the initial errors by publishing financial restatement announcements for further compensation. One of the earliest studies of the relationship between executive compensation and financial restatement was done by
Beneish (1999) [2]. Through the empirical test of the insider trading behavior and found that the managers sell more stock and exercise of stock options during the period of the surplus overvalued, regardless whether the transaction is illegal or not. He believes that senior managers adopt aggressive accounting policies in order to get high compensation. Burns and Kedia (2006) studied the relationship between financial restatement and executive option and found that managers will manipulate financial information to make the stock price rise and benefit from it. Burns and Kedia (2008) [3] made further research on this basis. The study selected the financial restatement companies in the period 1997-2002 as samples. It found that the size of the potential benefits of stock is positively related to the possibility of restatements. Compared with the same industry, the same scale companies, companies execute more stock options tend to adopt aggressive accounting policies and the size of option income is positively related to the restatements. The senior managers are not limited to the company's CEO and CFO. Harris and Bromiley (2006) reference agency theory and corporate behavior theory, empirical studies found that when the future value of option is nearly 20 times the basic salary, CEOs and other senior managers in order to pursue the maximization of individual interests will optimize performance data and manipulate stock price. Cheng and Farber (2008) focused on the probability of occurrence of financial restatement from the perspective of option compensation incentive plan. The study found two years after restatement announcement, option compensation plan will incentive the CEO use aggressive accounting policies, revise the real data, manipulate the financial report information, improve the company's profitability and market value, thus leading to the possibility of financial restatement greatly increased.

There are abundant foreign literatures study relationships between executive compensation and financial restatement; however, there are few studies on this area in China. Yu (2001) believes the long-term cooperation is built on the basis of credibility and integrity. It might get short-term benefits, but the bad credit will not disappear which will affect the future game results. The research of stock option based on the game theory found that managers hold stock options do not necessarily manipulate the stock price due to decreased motivation. Wei and Wang (2007) believe that managers have the motivation by selecting accounting policies and insider trading to make their own benefit maximization, their selfish behavior may cause the companies to adopt conservative 
accounting policy. You (2009) propose that the listed company executive compensation contracts and the new management clearing old account is also one of the internal causes of financial restatement. Wan and Chen (2011) believe that stock option compensation will strengthen the motivation of the financial restatements.

\section{B. Earnings Management}

Managers in order not to make the company's share price fell, by manipulating the financial statements to conceal their real earnings, and then, if necessary, through the financial restatement to correct. Defond and Jiambalvo (1991) first studied the relationships between earnings manipulation and financial restatement. The study took the companies with accounting errors of highly reported earnings as samples, confirmed that the misdescription of highly reported earnings is a means for managers to manipulate earnings. Kasznik (1996) found that, when the listed companies' earnings target cannot be achieved, executives often make forward earnings management by adjusting the non-accrual project. Richardson et al (2002) studied 403 restatement samples which from 1995 to1999, the results show that management of listed companies expected higher future earnings, tend to use more aggressive accounting policies and frequently issue financial statement. Callen et al (2006) [4] select the restatement companies from 1986 to 2001 as the research object, analysis the operating performance of the year when listed companies publish restatement announcements and the different data from previous years; it found that managers with opportunistic behavior by highly reporting earnings to increase personal income. Callen et al. (2008) further study found that the greater the loss of listed companies, manager is more likely to manipulate earnings through financial restatement.

Chinese scholars have done some research and found that companies with lower earnings quality have higher possibility publish the financial restatements reports. Yu (2007) proposed that the earnings management and earnings manipulation in order to cover up poor earnings situation is the reason of frequent financial restatement. Zhou (2011) believes that for those listed companies reported high earnings at first, and then publishes the restatement reports with low earnings, financial restatement it occurs mainly because managers manipulate the report and adjust the profits. Chen (2011) found that the accounting information quality of listed company with restatement is much lower than the company without restatement.

\section{Financing Needs}

Financing needs usually refers to the need for new projects, the need to repay the maturity debt, the lack of working capital and other reasons for capital requirement. Domestic and foreign scholars study shows that when a listed company have financing needs, it is more likely to occur financial. Dechow et al. (1996) studied the 66 companies that were punished by the relevant agencies of the United States because of illegal information disclosure, and found that the more intense the listed companies financing needs, the higher the possibility of financial restatements. Richardson et al. (2002) extends the research, found that managers often manipulate earnings of accounting statements before financing, in order to form the illusion of good development of the company, make external investors to invest, issue the financial restatement after collecting the funds.

Chen et al. (2000) found that listed companies in order to meet the requirements of allotment make the accounting treatment of high profit, issue a restatement announcement after the successful allotment to correct the error. Li and Shen (2012) believe that the listed companies which generate external financing needs or refinancing needs will very likely to occur financial restatements. It shows that the financial restatement and financing needs of listed company in China are positively correlated.

\section{CHARACTERISTICS OF THE COMPANY'S FINANCIAL RESTATEMENT}

\section{A. Financial Restatement and the Basic Characteristics of Company}

Ahmed et al. (2007) [1] believe that the larger the size of the company, the higher the credibility, the more perfect the system, the more transparent the information disclosure, the smaller the probability of financial restatement. In contrast, small-scale listed company's accounting system is relatively imperfect; the accounting treatment is more likely to make mistakes, there is a higher likelihood of financial restatement. Scholars have not reached a consensus. Burns et al. (2006) found that large scale listed company with more flexibility in the use of accounting standards on earnings manipulation, which leads to a higher chance of financial restatement. Richardson et al. (2002) found that there is no significant relationship between the size of the company and the probability of the occurrence of financial restatement, which shows that the scale of assets is not the decisive factor to the financial restatement.

Kinney and McDaniel (1989) found that compared with the company not restated, those with financial restatement have a small asset size, high debt ratio, low growth characteristics, and facing greater uncertainty in terms of future profitability, financing capacity. DeFond and Jiambalvo (1991) also noted in the study, compared with the control sample, the companies with bad operating conditions, lower profits, slow growth, imperfect corporate governance structure, rarely set up audit committee and dispersed ownership are more prone to conduct financial restatement. However, Richardson et al. (2002) found that, compared with the paired samples, the restatement company seems to have higher growth rates, but there is no difference in the size and profitability index. Ahmed and Goodwin (2006) found that the restatement companies in same industry have higher growth opportunities and smaller scale.

\section{B. Financial Restatement and Corporate Governance}

As the core of corporate governance, the board of directors plays an important role in the suppression of financial fraud, directly affect the quality of the company's financial information. Fama (1980) pointed out that the independence of board as an important safeguard to ensure the authenticity of accounting information, perform its basic functions and extent 
self-interested behavior. Beasley (1996) believes that the independence and size of the board are negatively related to the financial restatement. Dechow et al. (1996) [5] further study found that the proportion of independent directors in the board of directors is negatively correlated with the probability of financial restatement. Agrawal et al. (2005) found no correlation between board independence and financial restatement.

Dechow et al. (1996) found that the establishment of the audit committee and the independence of the audit committee are negatively related to the financial restatement. DeZoort et al. (2001) [7] pointed out that the lack of financial knowledge may restrict the audit committee judgment about reasonableness of the financial statements provided by the management, thus affecting the financial restatement. Abbott et al. (2004) further study found that audit committee size, meeting times and professional knowledge of members are negatively related to the financial restatement. Domestic scholars expand the study from the perspective of whether to set up an audit committee. Chen (2006) found that the company published restatement announcement rarely set audit committee. Huang (2010) believes that the establishment of the audit committee can reduce the frequency of financial statement and improve the quality of the financial report.

Kinney and McDaniel (1989) found that the ownership structure of restatements' company is more dispersed. Fama (1983) considered that the moderate ownership concentration not only effectively reduce agency costs, but also lead to the major shareholder pay more attention to the supervision of management. Ownership concentration can restrain the illegal behaviors such as earning manipulations, and then reduce the financial restatement. Zhang (2011) pointed out that highly concentrated ownership structure is beneficial to reduce the probability of financial restatement. Shleifer et al. (1986) believe that when ownership is too concentrated, the controlling shareholder based on the needs of their own interests, may take some means to plunder the interests of minority shareholders, giving rise to financial fraud. Jermias et al. (2005) believe that the financial fraud caused by the high concentration of shares will greatly increase the probability of financial restatement.

Goh et al. (2008) pointed out that one of the purposes of internal control is to prevent and detect material misstatement and omission may exist in the financial report, when there are defects in the internal control, the company's accounting conservatism is low, it is difficult to achieve this goal, and ultimately lead to the occurrence of the financial restatement. Liu (2012) confirmed that the companies with significant deficiencies in internal controls are more likely to have financial statements.

\section{ECONOMIC CONSEQUENCES OF FINANCIAL RESTATEMENT}

\section{A. Market Reaction}

Hribar and Jenkins (2004) [8] control the unexpected surplus and other factors; found that institutional investors will reduce the company's shares after the restatement announcement, and short-term institutional investors will reduce the company's shares before the restatement announcement which is more obvious. Demirkan (2007) found that, compared to small investors, large investors are more likely early to recognize the potential problem of companies' financial restatement, and take a more rational measures before and after the restatement.

GAO (2002) found that, after the financial restatement, the company stock prices will drop $10 \%$ in the next three trading days. Owers et al. (2002) divided the reasons into 9 categories, and found that the market reaction caused by different reasons is not the same, in which the negative financial restatement caused by accounting problems will bring the most serious negative market reaction. Callen et al. (2002) said that the financial restatement related to the company's revenue will bring the worst market reaction.

Wu (2002) found that the company which restatement caused by the SEC and other regulatory authorities urged to correct previous information assumes a greater loss than those voluntarily disclose restatement. Palmrose et al. (2004) [9] found that financial restatement of reduce profitability caused the biggest market reaction, followed by declining revenue report financial restatements. Financial restatements caused by the US SEC in the release date and the next day the average abnormal return of $-4 \%$, by the external auditors and internal initiation two day average abnormal return are as high as $-18 \%$ and $-13 \%$. Announcement caused by the external subject leads investors to question the ability and loyalty of managers, reduce the expectations of company's future operating conditions.

\section{B. Impact within the Company}

Hribar and Jenkins (2004) took 292 restatement companies as samples, found that the second month after the financial restatement, the cost of equity capital average increase of $7 \%$ to $19 \%$. Over time, the cost of capital has decreased, but there is still $6-15 \%$. The financial restatement published by the CPA has a significant positive correlation with the increase of the cost of capital. Kravet and Shevlin (2009) utilizing research data of GAO (2002) study on the relationship between financial restatement and the pricing of information risk, found that the risk of information increased significantly after the financial restatement, and led to the rise of the capital cost. Files and Gurun (2010) found that after the financial restatement, as the borrower, the loan interest rates of the same industry company increased by an average of 15 points, the loan interest rates of the main suppliers and customers and other related industries increased 14.7 points and 14.6 points respectively. He et al. (2013) took advantage of China's capital market data, found there were significant changes of bank lending rates, loans and protective provisions before and after the restatement, state owned companies can get bank more loans, the company with good system and environment can obtain higher loans and more relaxed constraints.

Srinivasan (2005) [10] found outside directors, especially audit committee members, get fired because of the financial restatement. Executive change is the reputation cost and penalties for managers in violation of accounting standards. 
Desai et al. (2004) [6] selected 146 companies in 1997-1998 occurred financial restatements as the samples, found that $60 \%$ of the company at least one of the executives is replaced in two years, only $35 \%$ of the matching sample firms in two years replaced executives. And nearly 92\% executives who were dismissed from the financial restatements company did not find the appropriate position, and the future is much worse than those dismissed from the paired sample company. Wang and Wei (2008) research showed that restatement company by changing the executives to improve the performance, and restore the damaged reputation; also may through the restructuring the board of directors to strengthen supervision on the managers; even hired a new director, in order to obtain the reputation and political capital.

Lev et al. (2007) found that compared to the other types of financial restatement, the elimination of the earnings growth pattern is more likely to lead to the decline in the stock return rate and litigation. Huber et al. (2004) study showed that the impact brought about by the financial restatement is not limited to the loss of market value, and it may lead to costly litigation and compensation. After the financial restatement, the interests of small shareholders damaged, in order to maintain their own interests may initiate class action which has a significant negative impact on the company's image and market expectations.

\section{CONCLUSIONS AND IMPLICATIONS}

Although there are many achievements in the study of financial restatement abroad, many conclusions remain controversial. The future related research can be improved from the following aspects. Find more effective methods and more unified rational Indices to further improve the empirical research. Strengthen the research depth, such as the research of industry contagion effect lays particular emphasis on the theoretical analysis, lack of empirical test.

At present, the domestic research on the financial restatement is still in the exploratory stage. Combined with the special institutional background in China and specific situation of listed company, the deep research on the financial restatement and used to guide practice is extremely necessary. It could study the financial restatement of different countries, to find the generality and characteristic of the phenomenon, so as to provide reference for China's financial supervision and system construction.

\section{ACKNOWLEDGMENT}

This paper is supported by (1)The Science and Technology Research Program of Hubei Provincial Department of Education of China; (2) Research Innovation Fund Program for Graduate Student of Jianghan University.

\section{REFERENCES}

[1] Ahmed K, Goodwin J. An empirical investigation of earnings restatements by Australian firms[J]. Accounting \& Finance, 2007, 47(1):1-22.

[2] Beneish M D. Incentives and Penalties Related to Earnings Overstatements that Violate GAAP $[\mathrm{J}]$. Accounting Review, 1999, 74(4):425-457.

[3] Burns N, Kedia S. Executive option exercises and financial misreporting[J]. Journal of Banking \& Finance, 2008, 32(5):845-857.

[4] Callen J L, Livnat J, Segal D. Accounting Restatements: Are They Always Bad News for Investors?[J]. Social Science Electronic Publishing, 2005, 18(1): 264-265.

[5] Dechow, P.M., R.G Sloan, A. Sweeney. Causes and Consequences of Earnings Manipulation: An Analysis of Firms Subject to Enforcement Actions by the SEC [J]. Contemporary Accounting Research, 1996,(13): $1-36$.

[6] Desai H, Hogan C E, Wilkins M S. The Reputational Penalty for Aggressive Accounting: Earnings Restatements and Management Turnover[J]. Accounting Review, 2004, 81(1):83-112.

[7] Dezoort F T, Salterio S E. The Effects of Corporate Governance Experience and Financial - Reporting and Audit Knowledge on Audit Committee Members' Judgments[J]. British Journal of Surgery, 2001, 38(149):52-64.

[8] Hribar P, Jenkins N T, Wang J. Institutional Investors and Accounting Restatements[J]. Ssrn Electronic Journal, 2004.

[9] Palmrose Z V, Richardson V J, Scholz S. Determinants of market reactions to restatement announcements $\hat{\tau}[\mathrm{J}]$. Journal of Accounting \& Economics, 2004, 37(1):59-89.

[10] Srinivasan S. Consequences of Financial Reporting Failure for Outside Directors: Evidence from Accounting Restatements and Audit Committee Members[J]. Journal of Accounting Research, 2005, 43(2):291-334. 